\title{
Antioxidant Enrichment and Antimicrobial Protection of Fresh-Cut Mango Applying Bioactive Extracts from Their Seeds By-Products
}

\author{
Violeta Vega-Vega, Brenda A. Silva-Espinoza, Manuel Reynaldo Cruz-Valenzuela, \\ Ariadna Thalía Bernal-Mercado, Gustavo A. González-Aguilar, Irasema Vargas-Arispuro, \\ Consuelo G. Corrales-Maldonado, J. Fernando Ayala-Zavala*
}

Centro de Investigacion en Alimentacion y Desarrollo, Carretera a la Victoria Km 0.6, La Victoria, Hermosillo, Mexico.

Email: ${ }^{*}$ jayala@ciad.mx

Received April $9^{\text {th }}, 2013$; revised May $9^{\text {th }}, 2013$; accepted May $16^{\text {th }}, 2013$

Copyright (C) 2013 Violeta Vega-Vega et al. This is an open access article distributed under the Creative Commons Attribution License, which permits unrestricted use, distribution, and reproduction in any medium, provided the original work is properly cited.

\begin{abstract}
The effect of the application of ethanolic extract of "Haden" mango seeds to increase the antioxidant and antimicrobial capacity of fresh-cut mango flesh was evaluated. Phenolic HPLC analysis revealed that gallic acid was the major identified compound in the ethanolic extract $(586.68 \mathrm{mg} / \mathrm{g})$. Fresh-cut mango was treated for immersion within the ethanolic extract, packed and stored at $5^{\circ} \mathrm{C}$ during 15 days. The content of phenolic compounds, antioxidant capacity and microbial growth of the treated mango were evaluated during the storage. Compared with the controls the treated fruit presented the highest content of the total phenolic (7.4 times), flavonoids (3.1 times), and antioxidant capacity DPPH', TEAC and ORAC $(2.9,2.3$ and 2.8 times, respectively), and showed a microbial reduction of $80 \%$ of mesophilic plate count and $97 \%$ of total molds. This study demonstrates the potential of phenolic compounds derived from mango seed as antimicrobials and antioxidants.
\end{abstract}

Keywords: Mangifera indica; Seed; Ethanolic Extract; Phenolic Compounds; Antioxidant Capacity; Antimicrobial Properties

\section{Introduction}

Mangoes are a good source of natural antioxidants. In addition to the usual nutrients, such as vitamins and minerals, mangoes are also rich in flavonoids and phenolic acids. Interest in the role of antioxidants in human health has promoted research in the field of food science to evaluate fruit and vegetable antioxidants and to determine whether their content and activity can be maintained or even improved through crop breeding, cultural practices, postharvest storage, fresh-cut processing, UV-C irradiation and the addition of plant extracts [1].

The antimicrobial and antioxidant activities of a variety of naturally occurring phenolics from different plant sources have been studied in detail [2-4]. The proposed mechanisms to explain the antimicrobial activity of these compounds include inhibition of extracellular microbial enzymes, deprivation of the substrates required for mi-

\footnotetext{
"Corresponding author.
}

crobial growth, or direct action on microbial metabolism through inhibition of oxidative phosphorylation or iron deprivation $[5,6]$. The ability of phenolic compounds to quench free radicals arises because of both their ability to donate protons and to transfer electrons while remaining relatively stable [7]. Therefore, plant phenolic compounds present remarkable antimicrobial and antioxidant potential $[6,8-10]$.

The phenolic content of byproducts obtained during the minimal processing of mango fruits has been analyzed. Fresh-cut mango is a demanded product, however, during its processing the generation of byproducts represents important economic and environmental issues [11]. Previously it has been observed that the byproducts from the varieties Haden and Ataulfo had the highest phenolic content, antioxidant and antimicrobial capacity [12]. Among tissues, seed showed the highest bioactive content and activity. The non polar fraccion of the ethanolic-extraction showed the highest phenolics, flavonoids, antioxidant and antimicrobial activity, followed by the methanolic-non-po- 
lar, methanolic-polar, ethanolic-polar fractions and water infusion, respectively. Combining factors, the ethanolicnon-polar extract obtained from seed and peel of mango "Ataulfo" and "Haden" had the highest bioactive properties. The quantities of mango seed byproducts yielded by its minimal processing are very high, which could represent an economic and environmental problem [13]. As an example in India, the mango processing industry annually generates $3 \times 10^{5}$ tons of seed approximately [13], representing the tissue from $9 \%$ to $40 \%$ by weight of the fruit. This demonstrates the potential that byproducts of fresh mango could have as a good source of functional extracts [12].

In this context, the objective of this study was to show the antimicrobial protection and the increment in the antioxidant capacity of fresh-cut mango (var. Haden) treated with ethanolic extract of their seed by-products.

\section{Materials and Methods}

\subsection{Sample Preparation}

Mangoes variety "Haden" were obtained from a local market in the city of Hermosillo, Sonora, Mexico. Mangoes were selected according to homogenous color and free of physical defects in a commercial maturity stage. Fruits were washed with chlorinated water $(250 \mathrm{ppm})$ for $3 \mathrm{~min}$ and air dried at $25^{\circ} \mathrm{C}$, and the peel and seed were removed, the pulp was cut into cubes of $2 \times 2 \mathrm{~cm}$. Seeds were used for the extraction of phenolic compounds.

\subsection{Preparation of Ethanolic Extract of Mango Seeds}

Ethanolic extracts of mango seeds was performed in accordance to a previously reported technique that showed to generate a potent in vitro antimicrobial and antioxidant extract [12]. The seed was weighted (10 g) and placed in containers with $100 \mathrm{~mL}$ of ethanol: water (7:3). The sample was left to macerate in darkness for 10 days at $25^{\circ} \mathrm{C}$. After that time, the extract was filtered and the solvent removed using a rotary evaporator at reduced pressure and temperature of $45^{\circ} \mathrm{C}$. The aqueous fraction was lyophilized, forming the dry extract, which was subject to alkaline hydrolysis $(10 \mathrm{~mL}$ of $\mathrm{NaOH} 4 \mathrm{M})$ for $4 \mathrm{~h}$ in the absence of light. Subsequently, an acid hydrolysis was performed with $\mathrm{HCl} 4 \mathrm{M}$ taken every sample to $\mathrm{pH} 2$. In the next step, the hydrolyzed extract was subject to liquid-liquid separation by 2 washes with $20 \mathrm{~mL}$ of ethyl acetate [14]. The ethyl acetate phase was used and evaporated; the obtained extract was re-suspended in de-ionized water to a concentration of $25 \mathrm{mg}$ of extract per $\mathrm{mL}$.

\subsection{Identification and Quantification of the Major Phenolic Compound in the Extract of Mango Seeds}

Identification and quantification of the major phenolic compound was completed by high performance liquid chromatography. We used a HP (1100) equipment with a quaternary pump and connected to a HP diode array detector at wavelengths of 280 and $320 \mathrm{~nm}$ was used. The equipment was controlled by Chem Station program for the acquisition and data analysis. The runs were performed with an analytical column Nucleosil $120 \mathrm{C}-18$ with dimensions of $250 \times 4.6 \mathrm{~mm}$, particle size of 5 micras. The used mobile phases were: $1 \%$ formic acid (A) and $100 \%$ acetonitrile (B), with a step gradient started with $98 \%$ formic acid and $2 \%$ acetonitrile, reaching $100 \%$ acetonitrile in $60 \mathrm{~min}$ at a flow of $0.5 \mathrm{~mL} / \mathrm{min}$ [15]. The running time was $75 \mathrm{~min}$ and the injection volume of $20 \mu \mathrm{L}$ of sample $(0.3 \mathrm{mg})$. The identification was made by comparison of UV spectra, using a database previously made with reference substances. Quantification was performed using standard curves of the corresponding compounds and reported as $\mathrm{mg}$ of the compound/g dry weight (dw).

\subsection{Application of Ethanolic Extract of Mango Seeds to Fresh-Cut Mango Flesh}

The fresh-cut mango was divided into two groups: control and treated $(25 \mathrm{mg} / \mathrm{mL}$ of ethanolic extract of mango seeds). The application of the extract was performed by immersion of $100 \mathrm{~g}$ of mango cubes for $2 \mathrm{~min}$ in the ethanolic extract and dried at room temperature for $30 \mathrm{~s}$. The control and treated fresh-cut fruit were packed in polypropylene trays and stored at $5^{\circ} \mathrm{C}$ during 15 days. Sampling was performed every 5 days to assess the effect of the extract applied on the content of phenolic compounds, antioxidant capacity and microbial populations (mesophilic aerobic microorganisms, total fungi and yeasts).

\subsection{Total Phenolic and Flavonoid Contents of Treated Mango Flesh}

Total phenol and flavonoids compounds were extracted from fresh-cut mango tissue $(10 \mathrm{~g})$, which was homogenized in a $15 \mathrm{~mL}$ of methanol $(80 \%)$ and sodium bisulfate $(0.5 \%)$. The homogenate was sonicated $30 \mathrm{~min}$ at $1{ }^{\circ} \mathrm{C}$, centrifuged at $1200 \mathrm{~g}$ for $15 \mathrm{~min}$ at room temperature (Beckman Coulter Centrifuge, Allegra 64R) and filtering. This was repeated two times with $10 \mathrm{~mL}$ of methanol $(80 \%)$, and the volume of pooled supernatant was brought up to $40 \mathrm{~mL}$. Total phenolic content was measured by the method described by Singleton and Rossi [16] with some modifications. The samples of the previous 
extraction $(50 \mu \mathrm{L})$ were mixed with $3 \mathrm{~mL}$ of $\mathrm{H}_{2} \mathrm{O}$ and $250 \mu \mathrm{L}$ of Folin-Ciocalteu's phenol reagent $1 \mathrm{~N}$. After 8 min of equilibration time, $750 \mu \mathrm{L}$ of $\mathrm{Na}_{2} \mathrm{CO}_{3}(20 \%)$ and $950 \mu \mathrm{L}$ of $\mathrm{H}_{2} \mathrm{O}$ were added to the mixture, and incubated for $30 \mathrm{~min}$ at room temperature. After incubation, the absorbance was read at $765 \mathrm{~nm}$ with an UV-Vis spectrophotometer (Cary, model 50 Bio, Varian, Italy). Concentration of total phenolic compounds was calculated using a standard curve of gallic acid equivalents (GAE) and expressed as milligrams per $100 \mathrm{~g}$ of fresh weight. Flavonoid content was determined based on the method described by Zhishen et al. [17] with slight modifications. One $\mathrm{mL}$ of each sample was mixed with $5 \% \mathrm{NaNO}_{2}$, $10 \% \mathrm{AlCl}_{3}$ and $1 \mathrm{~mol} / \mathrm{L} \mathrm{NaOH}$ and measured spectrophotometrically at $415 \mathrm{~nm}$ using quercetin as standard. The results were expressed as $\mathrm{mg}$ of quercetin equivalents $(\mathrm{QE})$ per $100 \mathrm{~g}$ of fresh weight.

\subsection{DPPH` Radical Scavenging Activity}

This assay is based on the measurement of the scavenging ability of antioxidants towards the stable radical DPPH' (2,2-diphenyl-1-picrylhydrazyl) [18]. A $3.9 \mathrm{~mL}$ aliquot of a $0.0634 \mathrm{mM}$ of DPPH" solution, in methanol was added to $0.1 \mathrm{~mL}$ of the methanolic extraction of mango flesh. The mixture was shaken in a vortex and kept 30 min in the dark. Absorbance was then read it in an UVVis spectrophotometer (Cary, model 50 Bio, Varian, Italy), at a wavelength of $515 \mathrm{~nm}$. Results were expressed in $\mathrm{DPPH}^{*}$ inhibition \%. Analyses were performed in triplicate.

\subsection{Trolox Equivalent Antioxidant Capacity (TEAC)}

This assay is based on the ability of the antioxidants to scavenge the blue-green $\mathrm{ABTS}^{++}$radical (2,2'-azino-bis(3ethy-lbenzothiazoline-6-sulphonic acid) compared to the scavenging ability of the water-soluble vitamin $\mathrm{E}$ analogue Trolox [19]. The $\mathrm{ABTS}^{\circ+}$ radical cation was generated by the interaction of $5 \mathrm{~mL}$ of $7 \mathrm{mM}$ ABTS solution and $88 \mu \mathrm{L}$ of $0.139 \mathrm{mM} \mathrm{K}_{2} \mathrm{~S}_{2} \mathrm{O}_{8}$ solution. After the addition of $2970 \mu \mathrm{L}$ of ABTS solution to $30 \mu \mathrm{L}$ of the methanolic extraction of mango flesh or trolox standards (0 to $20 \mu \mathrm{M}$ range), the absorbance was monitored 1 and 6 min after the initial mixing. The percentage of absorbance inhibition at $734 \mathrm{~nm}$ was calculated and plotted as a function of that obtained for the extracts and the standard reference (trolox). The final TEAC value was calculated by using a regression equation between the trolox concentration and the inhibition percentage and expressed as trolox equivalents ( $\mu$ mol TE) per $100 \mathrm{~g}$ of fresh weight.

\subsection{Oxygen Radical Absorbance Capacity Assay (ORAC)}

This assay measures the effect of antioxidant components in the sample on the decline in fluorescein fluorescence induced by a peroxyl radical generator, 2',2'-azobis (2amidino propane) dihydrochloride (AAPH) [18]. Different dilutions of Trolox $(200 \mu \mathrm{M}-12.5 \mu \mathrm{M})$ and methanolic mango samples were tested. All solutions were prepared fresh daily. In every working well the following was pipetted in triplicate: Fluorescein, $150 \mu \mathrm{l}$ of a $10 \mathrm{nM}$ solution; for standard, $25 \mu \mathrm{l}$ of Trolox dilution; for sample, $25 \mu \mathrm{l}$ of sample dilution; for blank, $25 \mu \mathrm{l}$ of phosphate buffer. The microplates were incubated at $37^{\circ} \mathrm{C}$ and fluorescence (Ex. $485 \mathrm{~nm}, \mathrm{Em} .520 \mathrm{~nm}$ ) were taken every $90 \mathrm{~s}$ using a BMG Labtech's multimode plate reader FLUOstar Omega. After 3 cycles, $25 \mu \mathrm{l}(240 \mathrm{mM})$ of AAPH was added manually with a multi-channel-pipette. The test was resumed and fluorescent measurements were taken up to 90 minutes. The final ORAC value of cut mango was calculated by using a regression equation between the trolox concentrations and the fluorescence intensity and expressed as $\mu \mathrm{mol}$ TE per $100 \mathrm{~g}$ of fresh weight.

\subsection{Microbial Growth in the Treated Mango}

Microbial growth was determined initially and during the storage period. Mangoes samples were diluted 1:9 in a solution containing $0.1 \mathrm{~g} / 100 \mathrm{~mL}$ of peptone and 0.5 $\mathrm{g} / 100 \mathrm{~mL}$ of sodium chloride and homogenized for $1 \mathrm{~min}$, subsequently 10 -fold dilutions were also made in this diluent. Each dilution was plated in duplicate for the different tested microorganisms. Aerobic plate count was incubated for 3 days at $30^{\circ} \mathrm{C}$ in plate count agar. Yeast and mold counts were incubated for 5 days at $25^{\circ} \mathrm{C}$ in potato dextrose agar. Total coliforms were measured by the solid medium method incubating samples for $24 \mathrm{~h}$ at $35^{\circ} \mathrm{C}$ using violet red bile agar. All analyses were performed according to the US Food and Drug Administration Bacteriological Analytical Manual methodology [20].

\subsection{Statistical Analysis}

The experimental design was completely randomized blocks, where the factors were the treatment $(0$ and 25 $\mathrm{mg} / \mathrm{mL}$ of ethanolic seed extract) and the time, which was blocked to see the effect of the treatment on the phenolic compounds, antioxidant capacity and microbial growth in mango cubes. Analysis of variance ANOVA was performed $(p \leq 0.05)$ to estimate significant differences between treatments, Tukey-Kramer was the mean test used for comparison $(\mathrm{p} \leq 0.05)$ performed with the Number Cruncher Statistical Systems [21]. 


\section{Results and Discussion}

\subsection{Identification and Quantification of the Major Phenolic Compound in the Ethanolic Extract of Mango Seeds}

Figure 1 shows the chromatogram corresponding for the ethanolic extract of mango seed. Three compounds were found, of which one was identified, corresponding to gallic acid as the main component of the extract, in a concentration of $586.68 \mathrm{mg} / \mathrm{g} \mathrm{dw}$, and with a retention time of $15.07 \mathrm{~min}$.

Previous studies by Abdalla et al. [22], reported that methanolic extracts obtained from the Egyptian mango seeds contain different phenolic compounds such as tannins $(20.7 \mathrm{mg} / 100 \mathrm{~g})$ and vainillin $(20.2 \mathrm{mg} / 100 \mathrm{~g})$. Also, was found gallic acid $(6.0 \mathrm{mg} / 100 \mathrm{~g})$, cumaric acid (12.6 $\mathrm{mg} / 100 \mathrm{~g})$, caffeic acid $(7.7 \mathrm{mg} / 100 \mathrm{~g})$, mangiferin $(4.2$ $\mathrm{mg} / 100 \mathrm{~g})$, ferulic acid (10.4 mg/100 g), cinnamic acid $(11.2 \mathrm{mg} / 100 \mathrm{~g})$ and unidentified compounds $(7.1 \mathrm{mg} /$ 100 g). Puravankara et al. [23], identified six phenolic compounds in mango seed extracts, especially gallic acid, ellagic and gallates. While Arogba [24], reported the presence of gallotannins and condensed tannins.

The differences in composition presented between the

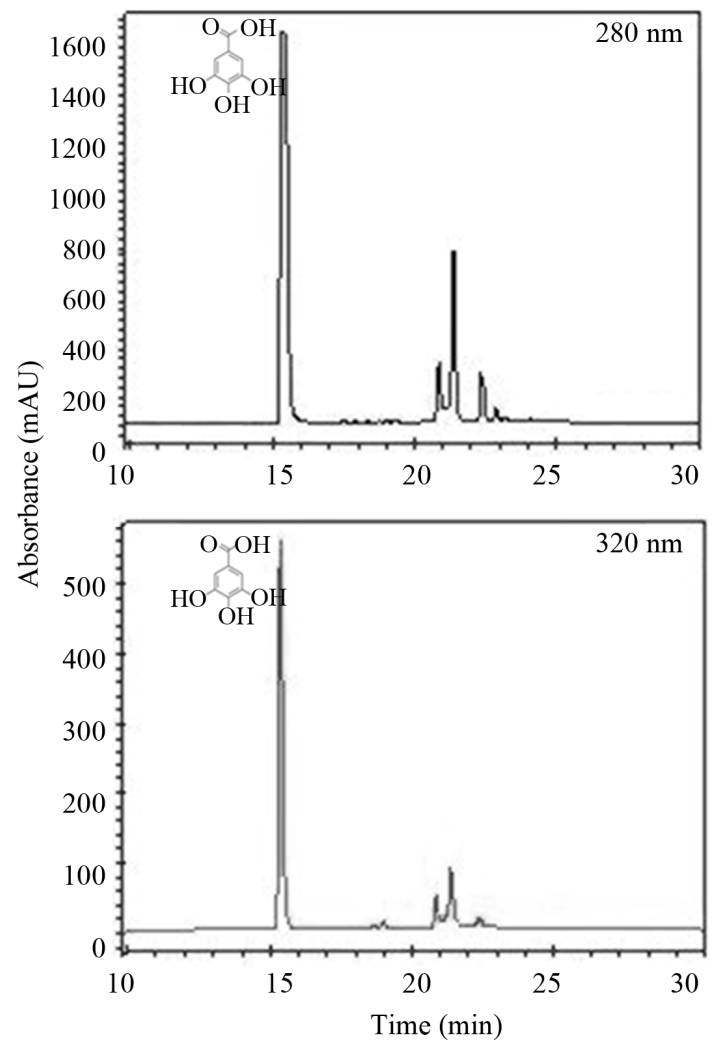

Figure 1. Phenolic compounds of the ethanolic extract of mango seed. Reverse phase chromatogram at 280 and 320 nm. extracts reported in the literature and in the present study may be due variety, degree of ripeness of the fruit used and the method of extraction. An important factor is the solvent used for the extraction of phenolic compounds, because solvents with different polarity extracted different compounds in varying quantities [25]. Another factor to consider is the hydrolysis with acids and bases [26], a step that was performed to development of the ethanolic extract, in where the tannins present in the mango seed could be hydrolyzed to simpler compounds such as gallic acid.

\subsection{Phenolic Compounds and Antioxidant Capacity of Fresh-Cut Mango}

Figures 2 and $\mathbf{3}$ show the phenolic content and antioxidant capacity of fresh-cut mango untreated and treated with the ethanolic extract of seeds. A significant effect ( $p$ $<0.05$ ) of the treatment on the phenolic content and antioxidant capacity of fresh-cut mango was found. Treated mango showed higher values of total phenolic and flavonoid compounds than the controls, being statistical differences between them. At the end of the storage, the the treated fresh-cut mango presented a highest content of the total phenolic (7.4 times), flavonoids (3.1 times), and antioxidant capacity evaluated for methods $\mathrm{DPPH}^{\circ}$, TEAC and ORAC (2.9, 2.3 and 2.8 times, respectively), compared to control. The ethanolic extract prepared from the mango seeds increased the antioxidant capacity of fresh-cut mango. In general, it was a positive correlation between phenolic content and antioxidant capacity, apparently such compounds are responsible for the antioxidant capacity in the mango fruit [27].

The usage of bioactive extracts applied to fruit presservation is an alternative to chemical preservatives and helps to achieve consumer demand for fresh, nutritious and safe fruits, and vegetables that are free of synthetic additives [4]. Presently, there are very few studies that provide information about the effect of bioactive compounds that are extracted from plant extracts and applied to fresh-cut fruits with the purpose of increasing the bioactive content $[2,3,6,9,28]$. However, the effect of antioxidant extracts obtained from fresh-cut mango byproducts as food preservatives has not been reported.

Some bioactive extracts have been proven to be effective antioxidants [4]. For example green tea extract has been evaluated as being able to act in the preservative treatment of fresh-cut lettuce. Different quality markers, such as respiration, browning, ascorbic acid, and carotenoid content were evaluated. Several tea extract concentrations $(0.25,0.5$, and $1 \mathrm{~g} / 100 \mathrm{~mL})$ at different temperatures $\left(20^{\circ} \mathrm{C}\right.$ and $\left.50^{\circ} \mathrm{C}\right)$ were tested. Optimal tea extract treatments $\left(0.25 \mathrm{~g} / 100 \mathrm{~mL}\right.$ at $\left.20^{\circ} \mathrm{C}\right)$ were compared with 


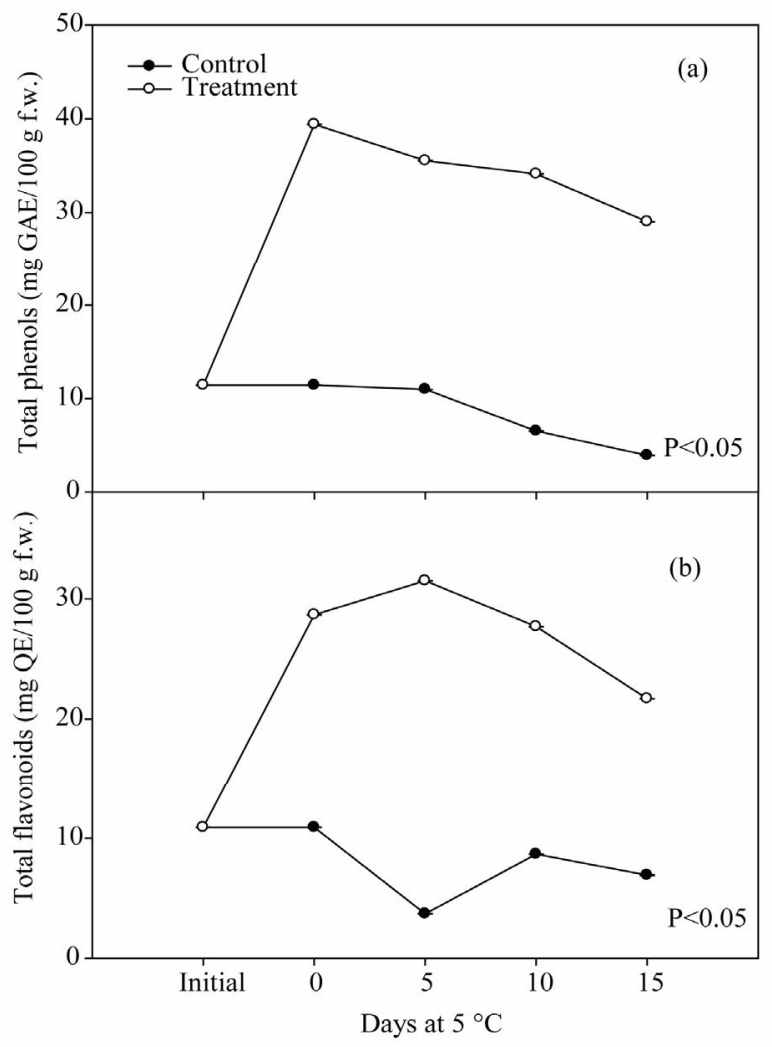

Figure 2. Changes on the total phenolic (a) and flavonoid (b) compounds of fresh-cut mango untreated and treated with the ethanolic extract of mango seeds, stored at $5^{\circ} \mathrm{C}$ during 15 days.

chlorine $\left(120 \mathrm{ppm}\right.$ at $\left.20^{\circ} \mathrm{C}\right)$. High tea extract concentrations $(0.5 \mathrm{~g} / 100 \mathrm{~mL}$ and $1.0 \mathrm{~g} / 100 \mathrm{~mL})$ prevented ascorbic acid and carotenoid losses. No significant differences were observed between chlorine and the optimal tea extract concentrations $\left(0.25 \mathrm{~g} / 100 \mathrm{~mL}\right.$ at $\left.20^{\circ} \mathrm{C}\right)$ in the browning appearance and sensory properties. Tea extract kept the antioxidant activity of the samples better than chlorine did [9].

\subsection{Microbial Growth on the Treated Mangoes}

Table 1 shows the antimicrobial activity of fresh-cut mango untreated and treated with the ethanolic extract of seeds, stored at $5^{\circ} \mathrm{C}$ during 15 days. A significant effect $(\mathrm{p} \leq 0.05)$ of the treatment on the growth of the mesophilic aerobic microorganisms and total fungi and yeast was found. On days 0 and 5 microbial counts were under the limit of enumeration, however, on days 10 and 15 the control had a higher population of these microorganisms, being statistical differences amongst them. At the end of the storage, the treatment inhibited the growth of mesophilic aerobic microorganisms, total fungi and yeast causing an $80 \%$ and $97 \%$ of microbial reduction compared to control fruit.

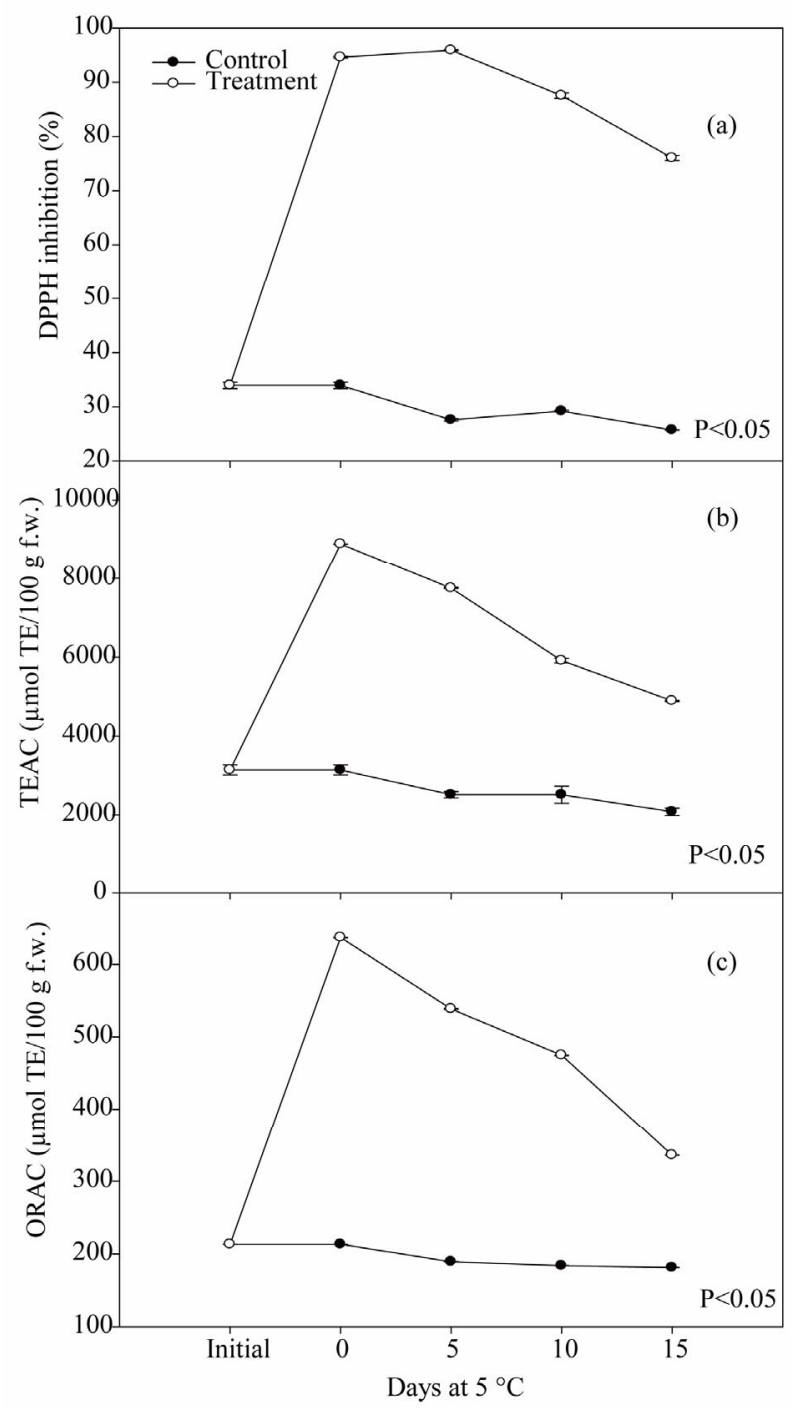

Figure 3. DPPH radical scavenging (a), TEAC (b) and ORAC (c) values of fresh-cut mango untreated and treated with the ethanolic extract of mango seeds, stored at $5^{\circ} \mathrm{C}$ during 15 days.

Table 1. Antimicrobial activity of fresh-cut mango untreated and treated with the ethanolic extract of mango seeds, stored at $5^{\circ} \mathrm{C}$ during 15 days.

\begin{tabular}{ccccc}
\hline & \multicolumn{2}{c}{$\begin{array}{c}\text { Mesophilic aerobic } \\
\text { microorganisms }\end{array}$} & \multicolumn{2}{c}{ Total fungi and yeast } \\
\cline { 2 - 5 } Days & Control & Treatment & Control & Treatment \\
\hline 0 & $<250 \pm 0^{*}$ & $<250 \pm 0$ & $<250 \pm 0$ & $<250 \pm 0$ \\
5 & $<250 \pm 0$ & $<250 \pm 0$ & $<250 \pm 0$ & $<250 \pm 0$ \\
10 & $19,000 \pm 605$ & $2000 \pm 48$ & $26,000 \pm 774$ & $<250 \pm 0$ \\
15 & $121,000 \pm 7315$ & $23,000 \pm 800$ & $472,000 \pm 341$ & $14,000 \pm 5567$
\end{tabular}

*Average of three determinations \pm standard error $(\mathrm{P}<0.05)$. 
No reports of the antioxidant capacity or the antimicrobial activity of extracts obtained from fruit byproducts as mango preservatives were found. But it has been reported that plant derived compounds like eugenol, thymol and carvacrol applied to grapes reduced growth of yeast, mold and mesophilic aerobics but the odor was detected after opening the package [10]. In addition, in a study with grapes wrapped in 2 distinct films having different permeabilities, and treated with or without the addition of a mixture of eugenol, thymol, and carvacrol [28], the microbial counts (of molds, yeasts, and mesophilic aerobics) drastically decreased, and consequently diminished berry decay.

Ethanolic extract of cinnamon bark $(1 \% \mathrm{w} / \mathrm{v})$ reduced the aerobic growth of bacteria inoculated fresh-cut apples significantly during storage at $6^{\circ} \mathrm{C}$ up to $12 \mathrm{~d}$. Catechin, chlorogenic acid, and phloridzin, 3 phenolic compounds that are abundant in apple processing byproducts, exhibited varying degree of inhibitory action toward the growth of tested food pathogenic and spoilage bacteria, fungi, and yeasts [2]. However, it is important to note that these phenolics (except $25 \mathrm{mM}$ phloridzin) did not inhibit the probiotic bacterium Lac. rhamnosus suggesting no or minimal threat to the beneficial colon microflora, if the phenolics are used as food additives at the desirable concentrations. Also these authors suggest that the major phenolic compounds of apple byproducts could find use as food additives. The use of natural, non-synthetic, additives is of great interest to the food industry due to consumer demand for products free of toxic residues. Therefore, there is a need to explore the possibility of using natural products with antioxidant and antimicrobial activity [29].

\section{Conclusion}

The application of ethanolic extract of mango seed byproducts from minimal processed mango enhance the increment of total phenolic content, antioxidant capacity, while inhibited the microbial growth of the treated mango flesh. This demonstrated the potential of phenolic compounds derived from mango seed as antimicrobials and antioxidants in the fresh-cut mango industry.

\section{Acknowledgements}

Authors thank the technical assistance of Monica Alejandra Villegas Ochoa and the financial support of the national council for science and technology CONACYT and the national program for the improvement of the professorate PROMEP.

\section{REFERENCES}

[1] J. F. Ayala-Zavala, S. Y. Wang, C. Y. Wang and G. A.
González-Aguilar, "Methyl Jasmonate in Conjunction with Ethanol Treatment Increases Antioxidant Capacity, Volatile Compounds and Postharvest Life of Strawberry Fruit," European Food Research and Technology, Vol. 221, No. 6, 2005, pp. 731-738. doi:10.1007/s00217-005-0069-Z

[2] S. Muthuswamy and H. P. V. Rupasinghe, "Fruit Phenolics as Natural Antimicrobial Agents: Selective Antimicrobial Activity of Catechin, Chlorogenic Acid and Phloridzin," International Journal of Food, Agriculture and Environment, Vol. 5, No. 3-4, 2007, pp. 81-85.

[3] S. Muthuswamy, H. P. V. Rupasinghe and G. W. Stratton, "Antimicrobial Effect of Cinnamon Bark Extract on Escherichia coli O157:H7, Listeria innocua and Fresh-Cut Apple Slices," Journal of Food Safety, Vol. 28, No. 4, 2008, pp. 534-549. doi:10.1111/j.1745-4565.2008.00129.x

[4] J. F. Ayala-Zavala, C. Rosas-Domínguez, V. Vega-Vega and G. A. González Aguilar, "Antioxidant Enrichment and Antimicrobial Protection of Fresh Cut Fruits Using Their Own Byproducts: Looking for Integral Exploitation," Journal of Food Science, Vol. 75, No. 8, 2010, pp. 175181.

[5] T. P. Cushnie and A. J. Lamb, "Antimicrobial Activity of Flavonoids," International Journal of Antimicrobial Agents, Vol. 26, No. 5, 2005, pp. 343-356.

doi:10.1016/j.ijantimicag.2005.09.002

[6] R. M. Raybaudi-Massilia, J. Mosqueda-Melgar, R. Soliva-Fortuny and O. Martin-Belloso, "Control of Pathogenic and Spoilage Microorganisms in Fresh-Cut Fruits and Fruit Juices by Traditional and Alternative Natural Antimicrobials," Comprehensive Reviews in Food Science and Food Safety, Vol. 8, No. 3, 2009, pp. 157-180.

[7] P. G. Pietta, "Flavonoids as Antioxidants," Journal of Natural Products, Vol. 63, No. 7, 2000, pp. 1035-1042. doi:10.1021/np9904509

[8] S. Burt, "Essential Oils: Their Antibacterial Properties and Potential Applications in Foods-a Review," International Journal of Food Microbiology, Vol. 94, No. 3, 2004, pp. 223-253. doi:10.1016/j.ijfoodmicro.2004.03.022

[9] A. B. Martín-Diana, D. Rico and C. Barry-Ryan, "Green Tea Extract as a Natural Antioxidant to Extend the ShelfLife of Fresh-Cut Lettuce," Innovative Food Science and Emerging Technologies, Vol. 9, No. 4, 2008, pp. 593-603. doi:10.1016/j.ifset.2008.04.001

[10] M. A. Rojas-Graü, R. M. Raybaudi-Massilia, R. C. Soliva-Fortuny, R. J. Avena-Bustillos, T. H. McHugh and O. Martín-Belloso, "Apple Puree-Alginate Edible Coating as Carrier of Antimicrobial Agents to Prolong Shelf-Life of Fresh-Cut Apples," Postharvest Biology and Technology, Vol. 45, No. 2, 2007, pp. 254-264. doi:10.1016/j.postharvbio.2007.01.017

[11] Y. Kim, J. K. Brecht and S. T. Talcott, "Antioxidant Phytochemical and Fruit Quality Changes in Mango (Mangifera Indica L.) Following Hot Water Immersion and Controlled Atmosphere Storage," Food Chemistry, Vol. 105, No. 4, 2007, pp. 1327-1334. doi:10.1016/j.foodchem.2007.03.050 
[12] V. Vega-Vega, "Enriquecimiento de la Capacidad Antioxidante y Protección Antimicrobiana del Mango Fresco Cortado Aplicando Compuestos Fenólicos de sus Subproductos," Master Thesis, Centro de Investigación en Alimentación y Desarrollo, A.C, Hermosillo, Sonora, Mexico, 2011.

[13] Y. Y. Soong and P. J. Barlow, "Antioxidant Activity and Phenolic Content of Selected Fruit Seeds," Food Chemistry, Vol. 88, No. 3, 2004, pp. 411-417. doi:10.1016/j.foodchem.2004.02.003

[14] G. Oboh and J. B. T. Rocha, "Distribution and Antioxidant Activity of Polyphenols in Ripe and Unripe Tree Pepper (Capsicum pubescens)," Journal of Food Biochemistry, Vol. 31, No. 4, 2007, pp. 456-473.

[15] M. J. Simirgiotis, P. D. S. Caligari and G. Schmeda-Hirschmann, "Identification of Phenolic Compounds from the Fruits of the Mountain Papaya Vasconcellea pubescens A. Dc. Grown in Chile by Liquid ChromatographyUv Detection-Mass Spectrometry," Food Chemistry, Vol. 115, No. 2, 2009, pp. 775-784. doi:10.1016/j.foodchem.2008.12.071

[16] V. L. Singleton and J. A. Rossi, "Colorimetry of Total Phenolics with Phosphomolybdic-Phosphotungstic Acid Reagents," American Journal of Enology and Vitiviniculture, Vol. 16, No. 3, 1965, pp. 144-158.

[17] J. Zhishen, T. Mengcheng and W. Jianming, "The Determination of Flavonoid Contents in Mulberry and Their Scavenging Effects on Superoxide Radicals," Food Chemistry, Vol. 64, No. 4, 1999, pp. 555-559. doi:10.1016/S0308-8146(98)00102-2

[18] J. F. Ayala-Zavala, S. Y. Wang, C. Y. Wang and G. A. González-Aguilar, "High Oxygen Treatment Increases Antioxidant Capacity and Postharvest Life of Strawberry Fruit," Food Technology and Biotechnology, Vol. 45, No. 2, 2007, pp. 166-173.

[19] R. Re, N. Pellegrini, A. Proteggente, A. Pannala, M. Yang and C. Rice-Evans, "Antioxidant Activity Applying an Improved ABTS Radical Cation Decolorization Assay," Free Radical Biology \& Medicine, Vol. 26, No. 9-10, 1999, pp. 1231-1237. doi:10.1016/S0891-5849(98)00315-3

[20] CFSAN/FDA, "Bacteriological Analytical Manual Online," 2001.

http://www.fda.gov/Food/FoodScienceResearch/Laborato ryMethods/ucm2006949.htm

[21] NCSS-Number Cruncher Statistical Systems, "Statisti- cal Program for Windows," Kaysville, Utah, 2007.

[22] A. E. M. Abdalla, S. M. Darwish, E. H. E. Ayad and R. M. El-Hamahmy, "Egyptian Mango By-Product 2: Antioxidant and Antimicrobial Activities of Extract and Oil from Mango Seed Kernel," Food Chemistry, Vol. 103, No. 4, 2007, pp. 1141-1152. doi:10.1016/i.foodchem.2006.10.026

[23] D. Puravankara, V. Boghra and R. S. Sharma, "Effect of Antioxidant Principles Isolated from Mango (Mangifera indica L.) Seed Kernels on Oxidative Stability of Buffalo Ghee (Butter Fat)," Journal of the Science of Food and Agriculture, Vol. 80, No. 4, 2000, pp. 522-526. doi:10.1002/(SICI)1097-0010(200003)80:4<522::AID-JS FA560>3.0.CO;2-R

[24] S. S. Arogba, "Mango (Mangifera indica) Kernel: Chromatographic Analysis of the Tannin, and Stability Study of the Associated Polyphenol Oxidase Activity," Journal of Food Composition and Analysis, Vol. 13, No. 2, 2000, pp. 149-156. doi:10.1006/jfca.1999.0838

[25] Y. C. Chen, J. T. Lin, S. C. Liu, P. S. Lu and D. J. Yang, "Composition of Flavonoids and Phenolic Acids in Lychee (Litchi chinensis Sonn.) Flower Extracts and Their Antioxidant Capacities Estimated with Human Ldl, Erythrocyte, and Blood Models," Journal of Food Science, Vol. 76, No. 5, 2011, pp. 724-728. doi:10.1111/j.1750-3841.2011.02164.x

[26] K. T. Chung, C. I. Wei and M. G. Johnson, "Are Tannins a Double-Edged Sword in Biology and Health?" Trends in Food Science \& Technology, Vol. 9, No. 4, 1998, pp. 168-175. doi:10.1016/S0924-2244(98)00028-4

[27] S. M. R. Ribeiro, L. C. A. Barbosa, J. H. Queiroz, M. Knödler and A. Schieber, "Phenolic Compounds and Antioxidant Capacity of Brazilian Mango (Mangifera indica L.) Varieties," Food Chemistry, Vol. 110, No. 3, 2008, pp. 620-626. doi:10.1016/j.foodchem.2008.02.067

[28] F. Guillen, P. J. Zapata, D. Martinez-Romero, S. Castillo, M. Serrano and D. Valero, "Improvement of the Overall Quality of Table Grapes Stored under Modified Atmosphere Packaging in Combination with Natural Antimicrobial Compounds," Journal of Food Science, Vol. 72, No. 3, 2007, p. 185. doi:10.1111/j.1750-3841.2007.00305.x

[29] K. N. Seneviratne and R. T. Kotuwegedara, "Antioxidant Activities of the Phenolic Extracts of Seed Oils and Seed Hulls of Five Plant Species," Food Science and Technology International, Vol. 15, No. 5, 2009, pp. 419-425. doi: $10.1177 / 1082013209352718$ 